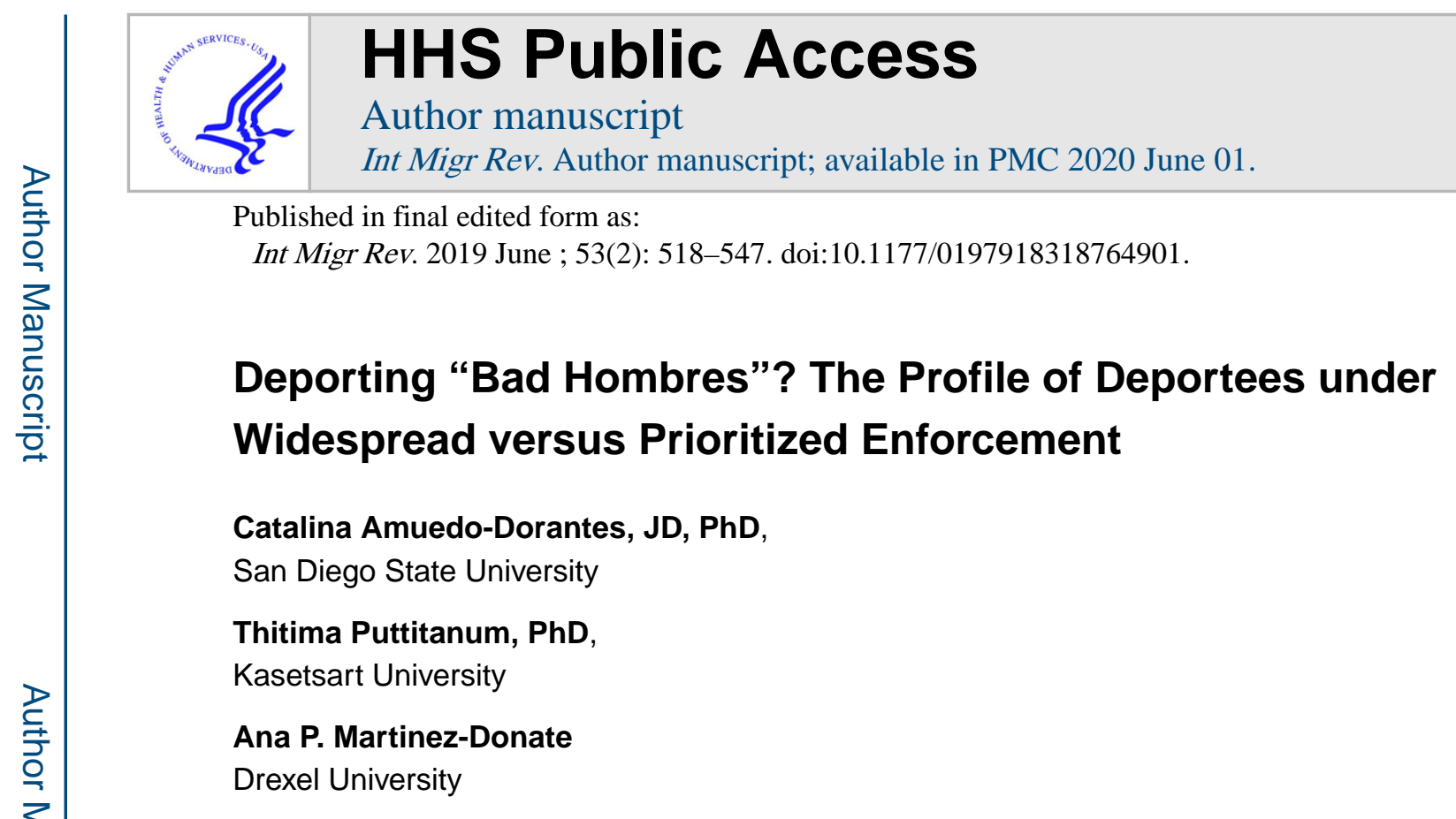

\begin{abstract}
U.S. President Trump's administration has vowed to boost immigration enforcement to get rid of "bad hombres," or undocumented immigrants with criminal records. Using past data on the alleged detention motives for a representative sample of Mexican deportees, we evaluate how prior widespread and prioritized enforcement has fared in that regard. We find that while the early sweeping approach to enforcement raised deportees' propensity of being detained for minor offenses, the trend reversed with prioritized enforcement. These findings inform policy tactics that, aside from proving effective in prioritizing serious criminal offenses, can also lead to significant savings to taxpayers.
\end{abstract}

\title{
JEL Codes
}

$\mathrm{K} 37 ; \mathrm{J} 15 ; \mathrm{J} 61$

\section{Keywords}

Undocumented Immigration; Immigration Enforcement; Deportation; United States

\section{Introduction}

Since 9/11, the United States has witnessed an unprecedented escalation of immigration enforcement at all levels: federal, state, and local (Chishti and Bergeron 2011, Mittelstadt et al. 2011). Federal initiatives, such as the Criminal Alien Program (CAP), along with border operations (e.g. Operation Streamline), have been accompanied by a number of immigration enforcement initiatives that have delegated the federal authority to carry out immigration enforcement tasks to local and state police personnel (Kandel 2016). Specifically, 287(g) agreements ${ }^{1}$ between Immigration Customs Enforcement (ICE) and local/state law 
enforcement agencies flourished after 2002, contributing considerably to an increase in the overall number of removals (see Figure 1). Although popular, these agreements were heavily disputed in a Department of Homeland Security (DHS) task force evaluation in 2011 (U.S. DHS 2011a), following allegations of racial profiling and discrimination (Provine and Sanchez 2011). Likewise, complaints that the vast majority of those arrested were charged with minor offenses or misdemeanors, ${ }^{2}$ such as traffic offenses and public drunkenness (Hagan et al. 2009, Koper et al. 2013), led DHS to progressively phase out the 287(g) agreements in favor of the Secure Communities program. ${ }^{3}$ Begun in 2008, Secure Communities was a cheaper local enforcement than 287(g) and emphasized community safety. Between 2009 and 2012, it resulted, on average, in about one million arrests and close to 400,000 removals of non-citizens on a yearly basis (Venturella 2010). The Secure Communities program expanded quickly, practically covering the entire United States by late 2014. In 2015, however, it was replaced by the Priority Enforcement Program, which targeted individuals convicted of significant criminal offenses or who otherwise posed a threat to public safety. ${ }^{4}$ In January 2017, under President Donald Trump's immigration regime, Secure Communities was reactivated. Across these different programs and despite their fine-tuning to target serious offenders, as well as the overall criminalization of unlawful entries, the vast majority of removals continued to be immigrants without a criminal status (Rosenblum and McCabe 2014).

To alleviate an increasingly overwhelmed detention and judicial system, DHS began to prioritize the apprehension, detention, and removal of individuals convicted of serious criminal offenses. ${ }^{5}$ However, the implementation of prosecutorial discretion 6 occurred at a slow pace. It was not until June 2012, following then DHS Secretary Janet Napolitano's suspension of deportations of "DREAMers" (National Immigration Forum 2013), ${ }^{7}$ that ICE officers were instructed not to place undocumented immigrants in removal proceedings or pursue a deportation order if they were considered "low priority." 8 Nevertheless, the average immigrant detainee continued to be a much less serious offender than the average prisoner in the criminal justice system, leading to the announcement in November 2014 of the extended

\footnotetext{
${ }^{1}$ Section $287(\mathrm{~g})$, codified at 8 U.S.C. $§ 1357(\mathrm{~g})$, was added by section 133 of the Illegal Immigration Reform and Immigrant Responsibility Act of 1996.

${ }^{2}$ In this regard, Figure A in the Appendix shows that the share of non-criminal deportations after 2012 dropped with respect to prior years.

${ }^{3}$ While both programs identify and place detainers on immigrants who have been arrested by local officers, putting the offenders on the path to removal, Secure Communities can only flag those immigrants whose fingerprints or identifying information is already in immigration database. In contrast, local officers in jurisdictions with $287(\mathrm{~g})$ agreements can determine the status of immigrants who have not had contact with immigration agents.

${ }_{5}^{4}$ See https://www.ice.gov/pep for details.

5 In June 2010, ICE Director John Morton released a memorandum signalling the agency's first steps toward a more focused enforcement. In June 2011, ICE further outlined the use of "prosecutorial discretion" to advance enforcement priorities. In terms of detention, under this memorandum, prosecutorial discretion applies to a broad range of enforcement decisions, including deciding whom to detain or to release on bond, supervision, personal recognizance, or other condition (National Immigration Forum 2013).

${ }^{6}$ Prosecutorial discretion may be exercised at any stage of an immigration case. Examples of the favorable exercise of prosecutorial discretion in the immigration context include a grant of deferred action; a decision to terminate or administratively close removal proceedings; a stay of removal; or a decision not to issue a charging document in the first place (see: https:// www.americanimmigrationcouncil.org/research/understanding-prosecutorial-discretion-immigration-law\#2).

7 The term "DREAMer" has been used to describe young undocumented immigrants who were brought to the United States as children, who have lived and gone to school here, and who in many cases identify as American. The term flows from the DREAM Act (Development, Relief and Education for Alien Minors Act) - a bill first introduced in Congress in 2001 to grant them legal status. ${ }^{8}$ The "low priority" group is Priority 3 in the enforcement priority list updated in 2014 by then DHS Secretary Jeh Johnson, whereas the "high priority" group includes those listed as Priority 1 and Priority 2. For details on who meet criteria for each priority group, please visit: https://www.dhs.gov/sites/default/files/publications/14_1120_memo_prosecutorial_discretion.pdf.
} 
Deferred Action for Childhood Arrivals (DACA) and the Deferred Action for Parents of Americans (DAPA) programs. ${ }^{9}$

These rapid changes in detention practices created a complicated legal landscape for undocumented immigrants and their allies. To date, however, we lack a systematic analysis of how the intensification of immigration enforcement starting in 2002 and subsequent DHS prioritization of serious criminal offenses altered the profile of deportees. Gaining a better understanding of the role played by different immigration enforcement approaches on the profile of deportees, however, is essential in the current policy environment. Curtailing unauthorized immigration was at the forefront of President Trump's campaign. As a candidate, he promised to increase border security through the construction of a wall along the U.S.-Mexico border, to initiate the deportation of two to three million undocumented immigrants with criminal records, to discontinue the DACA program, and to intensify immigration enforcement. ${ }^{10}$ On January 25, 2017, President Trump signed an executive order vastly expanding the pool of undocumented immigrants to be considered priorities for deportation, reversing the 2012 priority list. ${ }^{11}$ President Trump's administration has also sought the collaboration and cooperation of state and local enforcement agencies with DHS via threats to withhold federal funding to states and cities that attempt to shield undocumented immigrants. ${ }^{12}$ Therefore, learning about the success of refocusing apprehension, detention, and deportation efforts on serious criminal offenders, as opposed to implementing a far-reaching immigration enforcement approach, is critical, given the costs imposed by deportations on families, on the communities in which they reside, and on U.S. taxpayers. How effective were past immigration enforcement approaches at targeting serious criminal offenders? Did DHS's focused enforcement priorities after 2012 lower the share of deported immigrants arrested for minor offenses? Additionally, did the change in enforcement priorities affect detention times and operational costs borne by U.S. taxpayers?

We address these questions, using a rich dataset on deported Mexican immigrants that inquires about the circumstances surrounding their detention while in the United States, including the location, date, and rationale for their arrest (www.migrante.weebly.com). ${ }^{13}$ The MIGRANTE Project involves a series of cross-sectional, probability surveys of migrants traveling through the Tijuana-San Diego border region. Funded by the U.S. National Institutes of Health, the MIGRANTE surveys include, although are not restricted to, circular and undocumented Mexican migrants to and from the United States. ${ }^{14}$ They

9DACA was implemented by President Barack Obama in June 2012 and recently discontinued by President Trump in September 2017. DAPA was never implemented. For more information, please refer to: https://www.dhs.gov/sites/default/files/publications/ 14_1120_memo_prosecutorial_discretion.pdf.

${ }^{10}$ See: http://www.npr.org/2016/11/09/501451368/here-is-what-donald-trump-wants-to-do-in-his-first-100-days. In addition, President Trump has threatened to take away federal funds from localities that refuse to observe detainers sent by ICE, so-called ICE holds.

${ }^{11}$ See: https://www.whitehouse.gov/the-press-office/2017/01/25/executive-order-border-security-and-immigration-enforcementimprovements/.

12 https://www.nytimes.com/2017/03/27/us/politics/sanctuary-cities-jeff-sessions.html?_r=0.

${ }^{13}$ Despite decreased inflows of Mexican migrants to the United States, Mexicans still represent the largest unauthorized immigrant group in the United States. As of 2013, 6.2 million (56 percent) of the estimated 11 million unauthorized immigrants in the United States were from Mexico (http://www.migrationpolicy.org/article/mexican-immigrants-united-states).

${ }^{14}$ Circular migration, or repeat migration, is the temporary and usually repetitive movement of a migrant between home and host areas, typically for the purpose of employment. Although the MIGRANTE surveys use probability sampling to select a representative sample of migrants traveling along various migrant flows, circular migrants are more likely than "one-time" crossers to be selected to participate in the survey, given the greater frequency with which the former travel through the survey sites. 
contain a wealth of information on migration, health, and socio-economic factors, including the reasons and circumstances surrounding deported migrants' arrest, which can be used to increase understanding of this hard-to-reach population. Given our focus on the motives behind immigrant apprehensions leading to deportations, we use the MIGRANTE probability survey of deported Mexican migrants conducted from March 2014 to June 2015 in Tijuana, Mexico. We then merge detailed data on the implementation of various immigration enforcement initiatives at the state and county levels to gauge their impact, as well as that of DHS's prioritization of serious criminal offenses, on the profile of deportees as captured by the share detained for minor offenses.

We rely on a quasi-experimental approach that compares changes in the propensity of being arrested for a minor offense among deportees in counties that adopted tougher enforcement measures (treated counties) to those in counties that did not (control counties), before and after their implementation, as well as before and after DHS's later prioritization of serious criminal offenses. Our results reveal that while the intensification of immigration enforcement raised deportees' likelihood of being arrested for minor offenses, including traffic, disorderly conduct, and drug-use violations, such an event became less likely following DHS's prioritization of serious criminal offenses. Furthermore, the change in enforcement priorities from a widespread to a targeted strategy reduced deportees' length of time in detention, potentially saving U.S. taxpayers $\$ 81$ million.

Overall, the findings, which prove robust to a number of identification and robustness checks, underscore the legitimacy of complaints directed at DHS that the vast majority of those arrested were charged with minor offenses or misdemeanors as immigration enforcement intensified. In particular, they are consistent with qualitative reports and anecdotal evidence suggesting increased pressure on immigrant communities, heightened fear of deportation, and destabilization of immigrant families following the strengthening of enforcement efforts. ${ }^{15}$ Additionally, the results uncover the value of prioritizing the apprehension and deportation of serious criminal offenders in order to decrease the costs imposed on many mixed-status families, their communities, and, ultimately, U.S. taxpayers. Our hope is that these results refocus future discussions on immigration enforcement and provide evidence of the benefits of prioritizing serious criminal offenses at a time of aggressive immigration enforcement.

\section{Literature Review}

As noted earlier, the past two decades have witnessed many changes in immigration policies in the U.S., with the implementation of tougher immigration enforcement initiatives contributing to a vast increase in the number of removals since 2001 (Bipartisan Policy Center 2014). The expansion of immigration enforcement from the federal purview to a more fragmented local level through programs like 287(g) and Secure Communities not only

\footnotetext{
${ }^{15}$ See: https://www.americanprogress.org/wp-content/uploads/2012/08/DrebyImmigrationFamiliesFINAL.pdf; http://www.urban.org/ sites/default/files/alfresco/publication-pdfs/2000535-Implications-of-Immigration-Enforcement-Activities-for-the-Well-Being-ofChildren-in-Immigrant-Families-A-Review-of-the-Literature.pdf; http://ajph.aphapublications.org/doi/abs/10.2105/AJPH. 2014.302218, or http://abs.sagepub.com/content/58/13/1723.shortSDSU for examples. Language Hearing Clinic Diagnostic Evaluation
} 
considerably contributed to those statistics (Venturella 2010) but also changed the characteristics of those detained, according to a number of studies. For example, Donato and Rodriguez (2014) examine changes in arrest narratives before and after the adoption of a 287 (g) agreement in Nashville's Davidson County. They find that the reasons for stops changed substantially before and after the program's adoption, with minor violations, such as speeding, careless driving, running a stop sign or red light, or music/muffler/tint violations, representing a significantly greater share of police stops after $287(\mathrm{~g})$ went into effect. They also document how foreign-born residents, in particular, experienced an increase in pretextual stops -that is, stops involving greater officer discretion. In a similar vein, Koper et al. (2013) examine the effects that 287(g)'s implementation had on crime and disorderly conduct in Prince Williams County, ${ }^{16}$ Virginia. They find that although the number of arrests of undocumented immigrants rose substantially in 2008 and 2009, there were no significant changes in the types of crimes attributed to undocumented immigrants. Furthermore, the vast majority of undocumented immigrants who were arrested were charged with traffic offenses or misdemeanors.

Not only were most arrests for minor offenses, but a number of authors found a generalized practice of racial profiling nationwide. For example, Provine and Sanchez (2011) document how the implementation of 287(g) agreements and, later, SB1070 in Arizona led to more arrests based on appearance. Specifically, reasons for suspicion statements included "smelling like an illegal alien," "speaking only Spanish," or "looking dirty and soiled" (p. 474). Other reasons leading to stops involved the color of the skin, denim clothes, and playing Mexican music. While DHS responded to ongoing racial profiling and discrimination complaints that arose with the $287(\mathrm{~g})$ program by phasing out $287(\mathrm{~g})$ agreements in favor of the Secure Communities program, the latter did not help reduce the Federal Bureau of Investigation's overall index crime rate, as was initially advertised (Miles and Cox 2014). ${ }^{17}$ Despite its goal of keeping communities safer, the Secure Communities program soon triggered critiques from immigrant advocates and other social sectors, which noted that immigrant communities felt more insecure under this program (e.g. Capps et al. 2015, Sladkova et al. 2012, Valdez et al. 2013). A 2011 American Immigration Lawyers Association report found that many people entered deportation proceedings under Secure Communities, despite lacking a serious criminal history. The Transactional Records Access Clearinghouse (2014) examined millions of deportation records since the launch of Secure Communities and found that the program did not increase the removal of its primary targets, non-citizens who committed crimes other than minor violations. Instead, reports found, communities were being ripped apart, with impacts extending to businesses, parental school involvement, and overall community cohesiveness (Hagan et al. 2009). Heightened fear of the police among undocumented immigrants and their mixed-status families were also thought to lead to reductions in crime reporting (Sladkova et al. 2012). Moreover, in some instances, a private prison industry seeking to profit from the mass detention of immigrants

\footnotetext{
16Prince Williams County signed a 287(g) agreement in 2007.

${ }^{17}$ Miles and Cox (2014) note how only 28 percent of those detained and taken into federal custody under Secure Communities between November 2008 and November 2012 were Level 1 (most severe) offenders. About 40 percent were Level 2 or Level 3 (lower level offenders), and 32 percent were non-criminal offenders.
} 
was the greatest beneficiary of the interplay between immigration enforcement and the criminal justice system (Ackerman and Furman 2013, Martinez and Slack 2013).

In what follows, we exploit the temporal and geographic variation in the intensification of immigration enforcement at the local level to assess the extent to which the distinct approaches to immigration enforcement implemented by DHS from the early 2000s through 2015 shaped the profile of deportees. Specifically, for the first time, we assess how DHS's prioritization of serious criminal offenses following the intensification of immigration enforcement helped steer apprehension, detention, and deportation efforts away from minor offenders and toward serious criminal offenses after 2012. In addition, we explore if DHS's prioritization also impacted detention times and operational costs paid for by U.S. taxpayers.

\section{Data and Descriptive Statistics}

MIGRANTE Data-Our main data come from the MIGRANTE project, ${ }^{18}$ which surveys migrants as they arrive or depart from the border city of Tijuana, Mexico. Migrants eligible for the survey include 1) circular migrants returning from the U.S. to Mexican sending communities; 2) migrants traveling north from their communities of origin in Mexico; 3) migrants returning to their communities after a stay in the border region; and 4) migrants returning to Mexico forcedly, via deportation. Our focus is on this last group of migrants forcedly removed from the United States, with or without a formal deportation order. Even though the survey asks about arrests, it is worth keeping in mind that these are deportees. While the survey does not capture all Mexican deportees, it includes a probability sample of all deportees in Tijuana over the period of our study.

The MIGRANTE probability survey of deported Mexican migrants that we use was conducted between March 2014 and June 2015 in Tijuana, Mexico. In 2015, the San DiegoTijuana border region accounted for 8 percent of all U.S. Border Patrol apprehensions, ${ }^{19}$ and 14 percent of all deportations to the Mexican border region. ${ }^{20}$ Approximately 28,743 migrants were deported through Tijuana in 2015, of whom a target sample size of 1,800 was determined, based on power estimates. ${ }^{21}$ A total of 2,195 individuals were approached, and 2,145 were identified as eligible based on the screening survey. Of them, 2,136 agreed to participate and started the survey, with 2,038 completing the entire survey. The response rate

\footnotetext{
${ }^{18}$ See: www.migrante.weebly.com

${ }^{19}$ See: https://www.cbp.gov/sites/default/files/documents/BP\%20Total\%20Monthly\%20Apps\%20by\%20Sector\%20and\%20Area\%2C $\%$ 20FY2000-FY2015.pdf

${ }^{20}$ Cuadro 5.1 from: http://www.politicamigratoria.gob.mx/es_mx/SEGOB/Repatriacion_de_mexicanos_2015

${ }^{21}$ Sampling, recruitment, and data collection took place in El Chaparral, the only operating deportation facility in Tijuana. A probability-based sampling design was used to produce reliable estimates of the volume and characteristics of the deported Mexican migrant population returned to Mexico through Tijuana. Information on number of deportations through the Tijuana facility during the previous year and for different time periods within the year (e.g., quarter, day of the week, and time of the day) was obtained from the Mexican Institute of Migration to create a sampling framework and compute statistical weights. Sampling dates and times were randomly selected. During each 8-hour survey shift, trained project staff approached deported individuals immediately after they were cleared to leave the deportation facility and screened them for eligibility to participate in the survey. Two project staff members recruited participants simultaneously during each survey shift. Eligible individuals were 18 years and older, born in Latin America, returned to Mexico by U.S. immigration authorities, fluent in Spanish, and with no reported history of participation in the survey. By design, even if eligibility criteria did not require to be born in Mexico or a Mexican national, all migrants included in the MIGRANTE survey of deported migrants met at least one of these criteria. Otherwise, they would not have been deported to Mexico but to their respective countries (e.g. Salvadorians would be deported to El Salvador, Hondurans to Honduras, etc.). In the MIGRANTE sample of deportees, all but one respondent reported having been born in Mexico. Trained interviewers informed potential participants about the study and obtained verbal consent. The study included an interviewer-administered, computer-assisted interview.
} 
for the survey component, from which data for this study originated, was 95 percent. Survey weights were computed for each observation, following the general principles to estimate survey weights with multi-stage sampling procedures and to account for the survey design, eligibility rates, and response rates. ${ }^{22}$ The weighted sample represented an estimated population of 18,394 deported migrants. According to data from the Mexican Institute of Migration (Instituto Nacional de Migración), the actual number of migrants deported through Tijuana during the survey period was 17,589.

Immigration Enforcement Data-Our interest is in the role that changes in interior immigration enforcement had on deportees' propensity of being arrested for a minor offense. To that end, we first gathered data on state and county-level measures of immigration enforcement adopted over time in the locality in which the migrant resided while in the United States. Specifically, data on the enactment of state-level employment verification (EVerify) mandates, a key element in several Omnibus Immigration Laws (OIL), and data on OIL themselves were gathered from the National Conference of State Legislatures' website. 23 Data on the implementation of $287(\mathrm{~g})$ agreements and Secure Communities at the state and county levels were collected from the ICE 287(g) Fact Sheet website, ${ }^{24}$ from Kostandini et al. (2014), and from ICE's Activated Jurisdictions document, respectively (ICE 2013).

We then constructed an index intended to serve as a proxy for the intensity of interior immigration enforcement at the time and location where detention occurred. Our index is the sum of five dichotomous variables, each signaling the existence of an E-Verify mandate at the state level, a state-level OIL, a county-level 287(g) agreement, a state-level 287(g) agreement, and county-level participation in the Secure Communities program, respectively. Each of those five dummy variables equals 1 if the county in which the migrant was detained had adopted the measure in question (month, year) and 0 otherwise. The index is the sum of all five dummies at the time (month, year) and U.S. county where the deportee was detained. Therefore, it can fluctuate between 0 and 5, the number of immigration enforcement initiatives under consideration. Over the time period during which surveyed deportees were in the United States (1989-2015), this index averaged 0.6 (see Table 1). ${ }^{25}$

We merged the constructed immigration enforcement index with the MIGRANTE data, using information on the month and year when the migrant was arrested in the United States and the county in which s/he resided at the time of detention. As can be seen from Table A in the Appendix, the enforcement to which deportees in our sample were exposed rose steadily during the period examined. While the first immigration enforcement measure being considered was implemented in 2002, the first year when deportees in our sample were exposed to intensified enforcement is 2005. The immigration enforcement index grew from an average of 0.03 in 2005 to 0.97 by 2015 . Additionally, there was a significant degree of

${ }^{22}$ Equations used for computation of survey weights have been described elsewhere (Amuedo-Doranteset al. 2013).

23 http://www.ncsl.org

$24 \mathrm{https}: / / \mathrm{www} . i c e . g o v / 287 \mathrm{~g}$

${ }^{25}$ There are various advantages to using an index. Most notably, while no measure can perfectly capture the intensity of immigration enforcement, the index provides a more comprehensive way of measuring the interconnectedness of various immigration enforcement initiatives that overlap and/or are designed as a continuum of prior measures. 
regional variation in immigration enforcement, with the latter reaching higher levels in states like Arizona and lower levels in New York or Washington (see Table A).

\section{A) Descriptive Evidence}

Table 1 presents descriptive statistics for our sample of 1,148 deportees. ${ }^{26}$ We are interested in detentions for reasons we label as "minor" as they were more likely to be classified as misdemeanors. Our goal is to assess how the likelihood of being arrested and, subsequently, deported for such motives fared, when compared to deportations for serious crimes, following the initial intensification of immigration enforcement and DHS's subsequent prioritization of serious criminal offenses. About 11 percent of deportees reported a minor offense, ${ }^{27}$ which includes (a) a traffic offense, (b) disorderly conduct, and (c) drug use, as the trigger for their deportation. Traffic offenses were the most common ones, with 7.4 percent of deportees reporting them as the main motive for their apprehension and detention. Detentions for disorderly conduct and those related to drug use followed. Finally, for survey participants who were detained, the average duration of detention was about 262 days, with the average duration of migrant detentions being somewhat shorter in areas with intensified immigration enforcement than in their counterparts without.

Table 1 also shows some general characteristics of deportees in our sample. The vast majority are male ( 81 percent) and relatively young (on average, 34 years old).

Approximately 42 percent are married, and, for the most part, their educational attainment is low. Only 15 percent are high-school graduates, and only 4 percent have more than a highschool education. On average, they resided in the United States for about 12 years and were deported twice before. When distinguishing based on where they were arrested, we find that deportees who were arrested in areas with tougher enforcement were about 10 percentage points more likely to be male, 4 percentage points more likely to have graduated from high school, and had been in the United States 4 years longer than their counterparts in areas without such measures. However, they were about the same age, similarly likely to be married, and reported a similar number of previous removals.

\section{Methodology}

Our aim is to gain a better understanding of how DHS's prioritization of criminal offenses following the escalation of interior immigration enforcement shaped the detention profile of deportees after 2012. To that end, we consider the following benchmark regression model:

\footnotetext{
${ }^{26}$ We drop those observations in the MIGRANTE sample for which information on county of residence is unavailable. County of residence could only be ascertained for deportees residing in the 3-4 largest cities within a state. For the rest, the survey included information on state of residence but lacked information on the specific city and county of residence. This methodological issue results in an analytical sample that represents immigrants residing in large urban U.S. areas. The results may not be generalizable to migrants in rural areas. However, the vast majority of the unauthorized immigrant population resides in large metropolitan areas (Passel and Cohn, 2014).

${ }^{27}$ Detailed explanations of how our dependent variables are defined can be found in Table B. In particular, deportees are asked: "What was the reason you were detained this last time?" The dummy variable indicative of whether the detention was for a minor offense equals 1 if they answer: (a) Traffic violations, (b) disorderly conduct, or (c) drug use. Otherwise, it equals 0 , which include assaults, battery, attempted murder, murder, and homicide.
} 


$$
\begin{aligned}
& Y_{i c t}=\alpha+\beta_{1} E I_{c t}+\beta_{2} \text { After } 2012_{t}+\beta_{3} E I_{c t} * \text { After } 2012_{t}+X_{i c t} \gamma+\vartheta_{c}+\varphi_{t}+\vartheta_{c} t \\
& +\varepsilon_{i c t},
\end{aligned}
$$

where $Y_{\text {ict }}$ equals 1 if the $i^{\text {th }}$ deportee reported being arrested in county $c$ and year $t$ for a minor offense like a traffic, disorderly conduct, or drug-use violation. Otherwise, $Y_{i c t}$ equals zero. The vector $E I_{\mathcal{C} t}$ is the enforcement index in county ' $c$ ' where the deportee resided in the United States at time (month, year) ' $t$.' After $2012_{t}$ is a dummy indicative of whether the time period refers to the years after DHS's prioritization of serious criminal offenses, whereas the interaction term that follows allows us to assess how the latter change in policy altered the reasons for which deportees indicated being arrested.

Equation (1) includes the vector $X$, which contains information on a number of individuallevel characteristics, such as age, gender, indigenous ethnicity, ${ }^{28}$ marital status, educational attainment, years in the United States, and number of prior deportations for each deportee. We also incorporate a number of county fixed-effects $\left(\vartheta_{c}\right)$ and time fixed-effects $\left(\varphi_{t}\right)$ in our model to account for unobserved time-invariant characteristics possibly impacting detentions in a particular county and/or point in time. ${ }^{29}$ The aforementioned time-invariant characteristics allow us to address, respectively, circumstances such as whether the county has a sheriff particularly tough on immigration, as in the case of Arizona's notorious Maricopa County with Sheriff Arpaio (sheriff tenure 1993 - 2016), or whether it was an election year in the United States, during which politicians try to court voters with enforcement measures or initiatives. Finally, equation (1) also includes county-specific $\left(\vartheta_{c} t\right)$ time trends to capture other unobserved time-varying characteristics that might be playing a role yet are not explicitly controlled for, including the local-specific time trends for changing socio-economic conditions. ${ }^{30}$ Equation (1) is estimated as a linear probability model, and standards errors are clustered at the county level.

We are particularly interested in $\beta_{1}$ and $\beta_{3}$, which capture the role that intensified immigration enforcement and DHS's prioritization of serious criminal offenses played on the profile of deportees as captured by their propensity of being arrested for a minor offense. ${ }^{31}$ Specifically, we hypothesize that:

Hypothesis 1: Intensified immigration enforcement raised the propensity of being arrested for a minor offense -that is: $\beta_{1}>0$, whereas:

Hypothesis 2: DHS's later prioritization of serious criminal offenses helped lower the propensity of being arrested for a minor offense after 2012 , i.e. $\beta_{3}<0 .{ }^{32}$

\footnotetext{
${ }^{28}$ Ethnicity is included as another demographic trait potentially affecting the propensity of being detained in the presence of racial profiling, as suggested by the literature.

29 The term After $2012_{t}$ will naturally drop following the inclusion of year fixed-effects.

30 Additionally, in forthcoming robustness checks, we address the role played by other simultaneous and, to some degree, contradictory policies, such as the granting of driver licenses to undocumented immigrants or the passage of a Trust Act in the locality where the migrant resided (i.e. sanctuary localities).

${ }^{31}$ Note that we are working with a sample of deportees, all of whom have been detained and removed from the United States.

Therefore, when examining the likelihood of being arrested for a minor offense, the comparison group is composed of detentions for all other motives.

32 As suggested by a reviewer, we experimented with splitting the samples to two periods: prior to 2012 (including 2012) and after 2012.The qualitative results are the same as in Table 2. This test is available upon request.
} 


\section{Arrests under Widespread versus Prioritized Enforcement}

We estimate a number of model specifications that progressively add controls. Specification (1) in our tables of results is our baseline. Specification (2) adds a number of individual-level characteristics as control variables. Specification (3) further includes county fixed-effects to capture unobserved geographic traits potentially driving our estimates. Finally, specification (4) concludes by adding temporal controls, including time fixed-effects and county-specific time trends. We focus our discussion on the most complete model specification. In all instances, our reference category is deportees detained for non-minor offenses.

Our first set of results is displayed in Table 2, which assesses the likelihood of being arrested for a minor offense. We would expect the latter to increase as immigration enforcement intensified, as hypothesized in $H 1$. Indeed, according to the estimates in Table 2, the two were positively related until the change in DHS's apprehension and deportation priorities in 2012. As it turns out, after DHS's prioritization of serious criminal offenses, the propensity of being arrested for a minor offense versus a non-minor offense became lower as immigration enforcement intensified. ${ }^{32}$ Specifically, a one standard deviation increase in the intensity of immigration enforcement (roughly 50 percent of its average over the period under examination) raised the propensity of being arrested for a minor offense by 10 percentage points (68 percent) prior to $2012 .{ }^{33}$ However, that propensity became negative following ICE's targeted efforts on criminal offenses. The same one standard deviation increase in immigration enforcement now lowered the propensity of being arrested for a minor offense, relative to a non-minor offense, by 2.1 percentage points (15 percent). ${ }^{34}$

We next distinguish according to the type of minor offense: traffic, disorderly conduct, or drug-use violations. As shown in Table 3, prior to 2012, a one standard deviation increase in immigration enforcement raised the propensity of being arrested for a traffic, disorderly conduct, or drug-use offense by 7,4 , and 4 percentage points, respectively. These were very large increases, ranging from a 69 percent higher propensity following a traffic violation to a 2.5 times upsurge in the propensity of being arrested for a drug-use offense. This finding confirms qualitative reports in the literature (e.g. American Immigration Lawyers Association 2011, Frankel 2011). However, after DHS's prioritization of serious criminal offenses, the likelihood of being arrested for traffic, disorderly conduct, or drug-use violations dropped by 1 percentage point ( 8 percent), 1 percentage point (34 percent), and half a percentage point (34 percent), respectively. In sum, refocusing immigration enforcement efforts contributed to reducing detentions for minor offenses, as opposed to non-minor ones, after 2012, thus changing the prior trend in that regard.

\section{A) Identification Tests}

A main concern when examining any policy's impact using a quasi-experimental differencein-difference approach is whether the apparent impacts predated the policy change. To assess

\footnotetext{
${ }^{33}$ The impact is computed as $[(0.505=$ S.D. of EI among deportees residing in treated areas $) *($ coefficient on EI $) * 100]$ percentage points, which divided by the mean of the dependent variable for deportees in treated areas $(0.142)$, gives us the percent change. ${ }^{34}$ After $2012, \partial Y I \partial E I=\left[\beta_{E I}+\beta_{E I *}\right.$ After $2012 *$ After 2012$]=[0.191-0.233 * 1]=-0.042$. Therefore, a one standard deviation increase in the intensity of the EI would decrease the propensity of being arrested for a minor offense by $\left[(0.505) *(-0.042)^{*} 100\right]$ percentage points, which, divided by the mean of the dependent variable (0.142), gives us the percent change.
} 
whether that was the case here, we construct an indicator for the year before the immigration enforcement index for a particular county turned positive, which we include, along with the immigration enforcement index, in equation (1). If, indeed, the policy impact was anticipated or pre-existing, we should be able to find a statistically significant coefficient, with the same sign, on the term indicative of the year before the index turned positive in a given county. Panel A of Table 4 displays the result from such an exercise. It is evident that the observed changes in detention patterns did not take place prior to the adoption of tougher immigration enforcement measures in the county, as the coefficient for the preceding year is not statistically different from zero. Furthermore, the point estimates on the enforcement index continue to be statistically different from zero and of similar magnitude to the estimates from the most complete model specification in column (4) of Table 2 and Table 3.

Another concern with policy analyses is the possibility of reverse causality -in our case, whether the timing of the adoption of tougher immigration enforcement measures depended on the share of deportees being arrested for minor offenses. Therefore, we next collapse the data at the county level for the years prior to the time in which the immigration index turned positive in that particular county and model the year the county adopted any of the interior immigration measures under consideration as follows:

$$
\text { EI Year }{ }_{c}=\alpha+Y_{c}^{0} \mu+X_{c}^{0} \pi+\varepsilon_{c}
$$

Where $E I$ Year $_{c}$ is the year in which the enforcement index turned positive for county $c$. The vector $\mathrm{Y}_{\mathrm{c}}^{0}$ represents the average share of deportees indicating being arrested for a minor offense or for any of the specific minor offenses being studied prior to the enforcement index turning positive in that particular county (at point 0 ). The vector $X_{c}^{0}$ is the vector of controls in equation (1), now aggregated at the county-level, thus reflecting average county-level characteristics (e.g., the average share of male deportees, the average share married, or their average educational attainment in the county) prior to the implementation of tougher enforcement. We estimate equation (2) with state fixed effects and cluster standard errors at the state level. The results from this exercise are displayed in Panel B of Table 4. The county's average share of deportees detained for minor offenses prior to the adoption of stricter enforcement measures does not seem to play a significant role in the adoption timing of tougher immigration enforcement by the county, suggesting the lack of reverse causality.

\section{B) Robustness Checks}

In addition to the aforementioned identification tests, we conducted a number of robustness checks. First, we experimented with an alternative measure of intensified immigration enforcement. Instead of relying on an index, we created a simple dichotomous variable indicative of whether the migrant resided in a county among those in the top $25^{\text {th }}$ percentile in terms of its immigration enforcement intensity, what we refer to as a county with a high level of immigration enforcement. Results from estimating our models using this alternative dichotomous variable are shown in Panel A of Table 5. Overall, the key findings remain unchanged. In areas with tougher immigration enforcement, deportees detained prior to 
DHS's prioritization of serious criminal apprehensions were 52 percent more likely to have been detained for a minor offense than for a non-minor offense.

However, DHS's prioritization of serious criminal offenses in 2012 marked a sudden change. The propensity of being arrested for a minor offense in counties with a high intensity of immigration enforcement effectively reversed its sign, as we saw in Tables 2 and 3 using the index. Deportees indicated being 3 percent, 4.6 percent, and 1.5 percent less likely to be detained for overall minor offenses, disorderly conduct, and drug use after 2012, respectively, hinting on the redirection of efforts toward more serious offenses. The propensity of being arrested for traffic violations dropped as well, from being an event 33 percent more likely to take place prior to 2012 , to being practically no more likely (i.e. only 0.2 percent more likely) after 2012 .

As an alternative robustness check, we next assessed the role that the simultaneous implementation of more benevolent policies might have played on our estimates. To that end, we first looked at how the likelihood of being arrested for minor offenses varied across localities depending on whether they had a Trust Act. Trust Acts, enacted at the city, county, and state level, ${ }^{35}$ limit cooperation between local law enforcement and federal immigration authorities to increase the community's trust in the police and to facilitate communication between police and community residents. If the gauged impacts in Table 2 are, indeed, stemming from intensified immigration enforcement, as opposed to from an unobserved factor, we would expect the impact to be greater in areas without a Trust Act, where immigration enforcement is likely in full swing.

Results from such an exercise are displayed in Panel B of Table 5. Because the first Trust Act in our sample was not adopted until after 2012, the interaction term drops out. Still, prior to 2012, intensified immigration enforcement raised the likelihood of being arrested for a minor offense in non-sanctuary cities, whereas it had been decreasing in sanctuary cities. Hence, the impacts observed in Table 2 originate from intensified immigration enforcement in areas without a Trust Act.

To conclude, we performed a similar analysis looking, instead, at the role that the granting of driving licenses to undocumented immigrants might have had in the observed likelihood of being arrested for a traffic violation. As with the Trust Acts, the interaction term drops, as most of these were granted after 2012 in our sample. ${ }^{36}$ Still, it is clear from the estimates that the intensification of immigration enforcement practically had a null impact on the likelihood that deportees were arrested for a traffic violation, as opposed to for any other reasons, when they resided in localities that granted driving licenses to undocumented immigrants. In contrast, in what would be considered less permissive localities (i.e. those not granting a driver's license to an undocumented immigrant), a one standard deviation increase in immigration enforcement raised the likelihood of being arrested for a traffic violation by 7 percentage points ( 69 percent) prior to 2012 . This propensity dropped after 2012, as shown in Panel A of Table 3. Overall, the impact of intensified immigration

\footnotetext{
${ }^{35}$ Cities and states adopting these measures have been labelled "sanctuary cities," even though the Trust Acts do not impose any restrictions on federal law enforcement activities.

36 http://www.ncsl.org/research/immigration/states-offering-driver-s-licenses-to-immigrants.aspx
} 
enforcement stemmed, once more, from localities that were less permissive of undocumented immigration.

\section{C) Implications on the Length of Detention and DHS's Operational Costs}

Thus far, we have shown that the intensification of immigration enforcement was accompanied by a higher likelihood that deportees would be detained for minor offenses, including a traffic, disorderly conduct, or drug-use offense. Yet, that likelihood changed its sign with DHS's prioritized focus on serious criminal offenders after 2012. Furthermore, these impacts did not appear to be pre-existing or contaminated by potential reversecausality linkages of policies. Rather, they stemmed from tougher immigration enforcement, as is evident by the fact that they were present in localities without a Trust Act and, in the case of traffic violations, from those less likely to grant driving licenses to undocumented immigrants. They also appeared robust to the use of an alternative dichotomous immigration enforcement indicator.

A number of studies have documented the collateral damage of detentions and deportations on immigrants families, given that most detentions involved fathers and heads of household (Capps et al. 2016). ${ }^{37}$ In addition to these costs, there are operational costs. Despite ICE's more focused enforcement priorities, DHS requested $\$ 1.84$ billion for Custody Operations in Fiscal Year 2014, approximately \$5 million/day for immigrant detentions (National Immigrant Forum 2013). Hence, it is reasonable to ask if, in addition to reducing the likelihood of such unintended consequences, DHS's prioritization of serious criminal offenses in 2012 helped shorten detentions and decrease operational costs relative to the indiscriminate, sweeping immigration enforcement strategy that DHS is currently adopting under Trump's administration.

Table 6 looks at this question by examining how the intensification of immigration enforcement, as well as DHS's later prioritization of serious criminal offenses, impacted the length of time migrants were held prior to being deported. ${ }^{38}$ According to the estimates in the most complete specification, a one standard deviation in the immigration enforcement index raises the duration of immigrant detentions by 175 days prior to 2012. At the average daily cost of $\$ 159 /$ detainee and a capacity of 31,800 detainees (National Immigration Forum 2013), the increased duration translated into an additional $\$ 885$ million cost. ${ }^{39}$ With the announcement of DHS's more focused approach on immigration enforcement in 2012, detention duration dropped by 16 days, lowering the operational cost imposed by intensified immigration enforcement by $\$ 81$ million. ${ }^{40}$ By prioritizing the detention of serious criminal violators, the policy change might have helped lower the number of detainees held at detention centers, alleviating backlogs at immigration courts and reducing detention times. These figures, which represent a lower-bound estimated cost reduction if the overall number

\footnotetext{
${ }^{37}$ In this regard, Debry (2012a) notes how deportations have resulted in ripped-apart families and single-headed households struggling to make ends meet. The children belonging to such households often find themselves overburdened with adult responsibilities that interfere with their schooling progression (Menjivar 2006) and adversely impact their health and future employment outcomes (Brooks-Gunn et al. 1997; Brabeck and Qingwen Xu 2010; Hagan et al. 2010; Delva et al. 2013).

${ }^{38}$ The variable "Detention Duration" refers to the last detention/arrest in the United States, regardless of the reason for the detention or the authorities making the arrest.

39 Namely: $(175$ days $* \$ 159 /$ day $* 31,800$ detainees $)=\$ 884,835,000$.

40 That is: $(16$ days $* \$ 159 /$ day $* 31,800$ detainees $)=\$ 80,899,200$.
} 
of detentions were also dropping, emphasize just another cost of the earlier sweeping approach to immigration enforcement. This cost, however, is borne not just by deportees, their families, and the social fabric for the communities in which they had integrated, but also by U.S. taxpayers. Since the new immigration guidelines mark a significant overhaul of deportation policies under President Obama, the estimates above can potentially be a lower bound estimated cost that the U.S. taxpayers now must shoulder each year.

\section{Summary and Conclusions}

Since the signing of the first 287(g) agreement between ICE and the state of Florida in 2002, the United States has witnessed an intensification of immigration enforcement at the state and county levels that has been found to be responsible for 1.8 million deportations between 2009 and 2013 (Vaughan 2013). The increased number of removals, however, was accompanied by protests regarding racial profiling and growing public awareness of the many negative impacts of intensified enforcement on undocumented immigrants' family members, many of whom were U.S.-born children (Capps et al. 2016). DHS's prioritization of serious criminal offenses and ICE's more focused deportation efforts after 2012 came, partially, in response to such concerns.

In this analysis, we use a rich dataset on deported Mexican immigrants that inquires about circumstances surrounding their detention while in the United States, including the location, date, and rationale for their detention, and merge it with data on the implementation of a number of immigration enforcement initiatives at the state and county levels. Because of the many complaints about unsubstantiated stops, we look at how deportees' propensity of being arrested for minor offenses was impacted by the initially tougher approach to immigration enforcement seen in the mid- to late 2000s. We find that intensified interior immigration enforcement raised the propensity that deportees would indicate being arrested for a minor offense, including a traffic, disorderly conduct, or drug-use violation. Subsequently, we looked at whether the likelihood of such an event changed following DHS's refocused efforts on criminal arrests and deportations. The established enforcement priorities did steer DHS's focus away from minor offenses and reduced the length of time deportees were held in detention, pointing to potentially substantial savings in the order of $\$ 81$ million yearly.

This analysis underscores the truthfulness of complaints directed at DHS as immigration enforcement intensified, as well as the importance of prioritizing apprehensions and deportations of serious criminal offenders, given the costs imposed by deportations on families, on the communities in which they reside, and on U.S. taxpayers. In the absence of prioritized enforcement, local authorities appeared more likely to loosely interpret federal immigration laws, leading to more arrests and deportations for minor offenses. These findings are crucial in light of the sweeping changes in immigration policy under President Trump. The first major immigration raids under his administration manifested a clear shift in deportation strategy, one that, contrary to the President's claims during his campaign, is targeting undocumented immigrants without serious criminal records. ${ }^{41}$ Although official statistics about the number of arrests and deportations over the first 12 months of the Trump

41 http://www.usatoday.com/story/news/nation/2017/02/16/president-trump-immigration-raids-target-fewer-criminals/97988770/ 
administration are not yet available, ICE data from the first 100 days of the Trump administration suggest a dramatic switch from targeted to indiscriminate enforcement practices throughout the nation. Overall arrests have increased by 40 percent, and noncriminal arrests have risen by 150 percent when compared to the same period in the previous year. ${ }^{42}$ Particularly worrisome is the fact that these detentions are taking place more and more often at routine traffic stops or for minor traffic infractions (e.g. failure to signal a turn $)^{43}$ and in settings until now "off limits", such as courthouses and hospitals. ${ }^{44}$ As our study demonstrates, such an approach is dubiously effective at deporting "bad hombres" and will raise the DHS's operational costs to be paid for by U.S. taxpayers. More importantly, this broad approach will come at the cost of extraordinary suffering for thousands of families who contribute in many valuable ways to our diverse social fabric and will push immigrant communities (with and without legal status) further into the shadows and away from the American dream. Given the limited resources and the damage caused on many U.S. immigrant communities and the larger society around them, the findings underscore the value of prioritizing immigration enforcement and the need for a long-awaited comprehensive immigration reform.

\section{References}

Ackerman, A, Furman, R. The criminalization of immigration: Contexts and consequences. Durham, NC: Carolina Academic Press; 2014.

American Immigration Lawyers Association. [Accessed on October 12, 2016] Immigration Enforcement Off Target: Minor Offenses with Major Consequences. 2011. AILA InfoNet Doc. No. 11081609. August 2011. Available at: http://www.aila.org/File/Related/11081609.pdf

Amuedo-Dorantes, Catalina; Puttitanun, Thitima; Martinez-Donate, Ana P. 2013; How Do Tougher Immigration Measures Affect Unauthorized Immigrants? Demography. 50(3):1067-91. DOI: 10.1007/s13524-013-0200-x [PubMed: 23532619]

Bipartisan Policy Center. [Accessed on November 22, 2017] Issue Brief: Interior Immigration Enforcement by the Numbers. 2011. http://bipartisanpolicy.org/wp-content/uploads/sites/default/ files/files/Interior\%20Immigration\%20Enforcement.pdf

Brabeck K, Xu Qingwen. 2010; The Impact of Detention and Deportation on Latino Immigrant Children and Families: A Quantitative Exploration. Hispanic Journal of Behavioral Sciences. 32(3): 341-61.

Brooks-Gunn, Jeanne; Duncan, Greg J, Maritato, Nancy. Poor Families, Poor Outcomes: The WellBeing of Children and Youth. In: Duncan, D, Brooks-Gunn, Jeanne, editors. Consequences of Growing Up Poor. New York: Russell Sage Foundation; 1997.

Capps, Randy; Castaneda, Rosa Maria; Chaudry, Ajay; Santos, Robert. Paying the Price: The Impact of Immigration Raids on America's Children. The Urban Institute; Washington, DC: 2007.

Chishti, Muzaffar; Bergeron, Claire. Post-9/11 Policies Dramatically Alter the U.S. Immigration Landscape. Vol. 2011. Migration Policy Institute; 2011. Available at: https:// www.migrationpolicy.org/article/post-911-policies-dramatically-alter-us-immigration-landscape [Accessed on November 22, 2017]

Delva, Jorge; Horner, Pilar; Martinez, Ramiro; Sanders, Laura; Lopez, William D; Doering-White, John. 2013; Mental Health Problems of Children of Undocumented Parents in the United States: A Hidden Crisis. Journal of Community Positive Practices. 13(3):25-35.

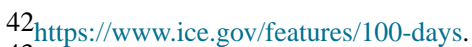

43 https://www.nytimes.com/2017/11/25/us/atlanta-immigration-arrests.html.

44 http://www.nydailynews.com/new-york/ice-courthouse-arrests-immigrants-900-n-y-2017-article-1.3633463. https:// jamanetwork.com/journals/jama/fullarticle/2658246.
} 
Donato, Katherine M; Rodriguez, Leslie A. 2014Police Arrests in Time of Uncertainty: The Impact of 287(g) on Arrests in a New Immigrant Gateway. American Behavioral Scientist. :1-27.

Dreby, Joanna. How Today's Immigration Enforcement Policies Impact Children, Families, and Communities: A View from the Ground. Center for American Progress; 2012a.

Frankel, Elizabeth. 2011; Detention and Deportation with Inadequate Due Process: the Devastating Consequences of Juvenile Involvement with Law Enforcement for Immigrant Youth. Duke Forum for Law and Social Change. 63Accessed on October 12, 2016

Hagan, Jacqueline; Castro, Brianna; Rodriguez, Nestor. 2010; The Effects of U.S. Deportation Policies on Immigrant Families and Communities: Cross-Border Perspectives*. North Carolina Law Review. 88:1799-1824.

ICE. [Accessed May 23, 2014] Activated Jurisdictions. 2013. Available at: http://www.ice.gov/doclib/ secure-communities/pdf/sc-activated.pdf

Instituto Nacional de Migración. Centro de Estudios Migratorios. [Accessed on January 11, 2012] Estadísticas Migratorias. Boletines Estadísticos. Boletín Mensual de Estadísticas Migratorias. 2010. Available at: http://www.inm.gob.mx/estadisticas/2010/BoletinEst2010.pdf

Kandel, William A. Congressional Research Service Report R44627. 2016. Interior Immigration Enforcement: Criminal Alien Programs.

Koper, Christopher S; Guterbock, Thomas M; Woods, Daniel J; Taylor, Bruce; Carter, Timothy J. 2013; The Effects of Local Immigration Enforcement on Crime and Disorder. Criminology\& Public Policy. 12(2):239-276.

Kostandini G, Mykerezi E, Escalante C. 2013; The Impact of Immigration Enforcement on the U.S. Farming Sector. American Journal of Agricultural Economics. 96(1):172-192.

Legislature, National Conference of State. State Omnibus Bills and Laws. 2011. http://www.ncsl.org/ documents/statefed/omnibus_laws.pdf

Legislatures, National Conference of State. State E-Verify Laws. 2012. http://www.ncsl.org/research/ immigration/everify-faq.aspx\#2012 State Action

Martinez, Daniel; Slack, Jeremy. 2013What Part of "Illegal” Don’t You Understand? The Social Consequences of Criminalizing Unauthorized Mexican Migrants in the United States. Social\& Legal Studies. :1-17.

Menjivar, Cecilia. 2006; Liminal Legality: Salvadoran and Guatemalan Immigrants' Lives in the United States. American Journal of Sociology. 111(4):999-1037.

Miles, Thomas J; Cox, Adam B. 2014; Does Immigration Enforcement Reduce Crime? Evidence from "Secure Communities. Journal of Law \& Economics. 57(4):937- 973.

Mittelstadt, Michelle; Speaker, Burke; Meissner, Doris; Chishti, Muzaffar. [Accessed on November 22, 2017] Through the Prism of National Security: Major Immigration Policy and Program Changes in the Decade since 9/11. Migration Policy Institute Fact Sheets. 2011. Aug, https://

www.migrationpolicy.org/research/post-9-11-immigration-policy-program-changes

National Immigration Forum. The Math of Immigration Detention: Runaway Costs for Immigration Detention Do Not Add Up to Sensible Policies. Washington DC: 2013.

Provine MD, Sanchez G. 2011; Suspecting immigrants: Exploring links between racialist anxieties and expanded police power in Arizona. Policing\& Society. 21(4):468-479.

Rosenblum, Marc R; McCabe, Kristen. 2014 Deportation and Discretion: Reviewing the Record and Options for Change. Migration Policy Institute Report. Oct.

Santibáñez, J. Metodología de la encuesta sobre migración en la Frontera Norte de México. In: Bustamante, JA, Delaunay, D, Santibañez, J, editors. Taller de medición de la migración internacional. El Colegio de la Frontera Norte: ORSTOM; 1997. 206-229.

Sládková J, Garcia Mangado SM, Reyes Quinteros J. 2012; Lowell immigrant communities in the climate of deportations. Analyses of Social Issues and Public Policy. 12:78-95. DOI: 10.1111/j. 1530-2415.2011.01253.x

Transactional Records Access Clearing house. 2014Secure Communities and ICE Deportation: A Failed Program?

U.S. Department of Homeland Security - U.S. Customs and Border Protection - U.S. Border Patrol U.S. Border Patrol Fiscal year Apprehension Statistics. [Accessed on January 27, 2016] Available at: http://www.cbp.gov/linkhandler/cgov/border_security/border_patrol/apps.ctt/apps.pdf 
U.S. Department of Homeland Security. [Accessed on March 18, 2017] Yearbook of Immigration Statistics. 2008. Available at: https://www.dhs.gov/immigration-statistics/yearbook

U.S. Department of Homeland Security. [Accessed on March 18, 2017] Yearbook of Immigration Statistics. 2010. Available at: https://www.dhs.gov/immigration-statistics/yearbook

U.S. Department of Homeland Security. [Accessed on March 18, 2017] Yearbook of Immigration Statistics. 2012. Available at: https://www.dhs.gov/immigration-statistics/yearbook

U.S. Department of Homeland Security. [Accessed on March 18, 2017] Yearbook of Immigration Statistics. 2013. Available at: https://www.dhs.gov/immigration-statistics/yearbook

U.S. Department of Homeland Security. [Accessed on March 18, 2017] Yearbook of Immigration Statistics. 2014. Available at: https://www.dhs.gov/immigration-statistics/yearbook

U.S. Department of Homeland Security. [Accessed on March 18, 2017] Yearbook of Immigration Statistics. 2015. Available at: https://www.dhs.gov/immigration-statistics/yearbook

Valdez CR, Padilla B, Valentine JL. 2013; Consequences of Arizona's immigration policy on social capital among Mexican mothers with unauthorized immigration status. Hispanic Journal of Behavioral Sciences. 35(3):303-322.

Venturella, David J. 2010 Secure Communities: Identifying and Removing Criminal Aliens. The Police Chief. 77Sep.:40-49.

\section{APPENDIX}




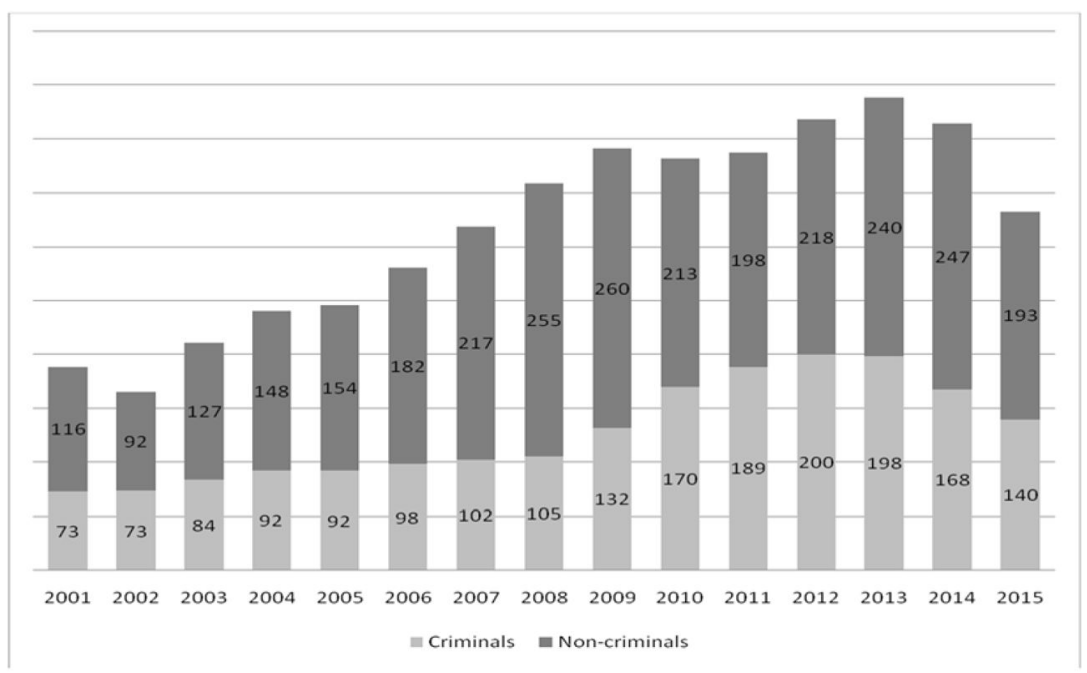

Figure A. Deportations by criminal status

(In thousands, by fiscal year)

Source: Data for 2001-2003 come from U.S. Department of Homeland Security, Yearbook of Immigration Statistics: 2010. Data for 2004-2013 come from U.S. Department of Homeland Security, Yearbook of Immigration Statistics: 2013. Data for 2014 and 2015 come from Yearbook of Immigration Statistics: 2014 and 2015, respectively.

Table A

Intensity of Interior Enforcement by City

\begin{tabular}{|c|c|c|c|c|}
\hline State & City & 2005 & 2010 & 2015 \\
\hline \multirow[t]{4}{*}{ Arizona } & Phoenix & 0.33 & 4.75 & 3 \\
\hline & Tucson & 0.33 & 4.75 & 2 \\
\hline & Tempe & 0.33 & 4.75 & 3 \\
\hline & Scottsdale & 0.33 & 4.75 & 3 \\
\hline \multirow[t]{5}{*}{ California } & Los Angeles & 0.92 & 2 & 1 \\
\hline & San Diego & 0 & 1 & 0 \\
\hline & San Jose & 0 & 0 & 0 \\
\hline & San Francisco & 0 & 0.58 & 0 \\
\hline & Fresno & 0 & 0 & 0 \\
\hline \multirow[t]{4}{*}{ Colorado } & Denver & 0 & 2 & 1 \\
\hline & Colorado Springs & 0 & 2 & 1 \\
\hline & Boulder & 0 & 2 & 1 \\
\hline & Aspen & 0 & 2 & 1 \\
\hline \multirow[t]{3}{*}{ Delaware } & Wilmington & 0 & 1 & 0 \\
\hline & Dover & 0 & 1 & 0 \\
\hline & Newark & 0 & 1 & 0 \\
\hline \multirow[t]{3}{*}{ Georgia } & Atlanta & 0 & 2.33 & 2 \\
\hline & Savannah & 0 & 2 & 2 \\
\hline & Marietta & 0 & 2 & 2 \\
\hline
\end{tabular}

Int Migr Rev. Author manuscript; available in PMC 2020 June 01. 


\begin{tabular}{|c|c|c|c|c|}
\hline State & City & 2005 & 2010 & 2015 \\
\hline \multirow[t]{3}{*}{ Idaho } & Boise & 0 & 1 & 1 \\
\hline & Nampa & 0 & 1 & 1 \\
\hline & Pocatello & 0 & 1 & 1 \\
\hline \multirow[t]{3}{*}{ Illinois } & Chicago & 0 & 1 & 1 \\
\hline & Springfield & 0 & 1 & 1 \\
\hline & Peoria & 0 & 1 & 1 \\
\hline \multirow[t]{3}{*}{ Indiana } & Indianapolis & 0 & 0 & 2 \\
\hline & Fort Wayne & 0 & 0 & 2 \\
\hline & South Bend & 0 & 0 & 2 \\
\hline \multirow[t]{3}{*}{ Michigan } & Detroit & 0 & 1 & 1 \\
\hline & Grand Rapids & 0 & 0 & 1 \\
\hline & Ann Arbor & 0 & 0 & 1 \\
\hline \multirow[t]{3}{*}{ Nevada } & Las Vegas & 0 & 1.5 & 0 \\
\hline & Reno & 0 & 0 & 0 \\
\hline & Carson City & 0 & 0 & 0 \\
\hline \multirow[t]{3}{*}{ New Mexico } & Albuquerque & 0 & 1 & 0 \\
\hline & Santa Fe & 0 & 1 & 0 \\
\hline & Las Cruces & 0 & 1 & 0 \\
\hline \multirow[t]{3}{*}{ New York } & New York City & 0 & 0 & 0 \\
\hline & Buffalo & 0 & 0 & 0 \\
\hline & Albany & 0 & 0 & 0 \\
\hline \multirow[t]{3}{*}{ North Carolina } & Raleigh & 0 & 0 & 1 \\
\hline & Charlotte & 0 & 2 & 2 \\
\hline & Asheville & 0 & 0 & 1 \\
\hline \multirow[t]{3}{*}{ Oklahoma } & Oklahoma City & 0 & 1 & 1 \\
\hline & Tulsa & 0 & 1 & 1 \\
\hline & Norman & 0 & 1 & 1 \\
\hline \multirow[t]{3}{*}{ Oregon } & Portland & 0 & 0.67 & 0 \\
\hline & Eugene & 0 & 0 & 0 \\
\hline & Bend & 0 & 0 & 0 \\
\hline \multirow[t]{3}{*}{ Pennsylvania } & Philadelphia & 0 & 1 & 1 \\
\hline & Pittsburgh & 0 & 0 & 1 \\
\hline & Harrisburg & 0 & 0 & 1 \\
\hline \multirow[t]{3}{*}{ South Carolina } & Charleston & 0 & 0 & 2 \\
\hline & Myrtle Beach & 0 & 0 & 2 \\
\hline & Columbia & 0 & 0 & 2 \\
\hline \multirow[t]{3}{*}{ Tennessee } & Nashville & 0 & 1 & 1 \\
\hline & Knoxville & 0 & 1 & 1 \\
\hline & Memphis & 0 & 1.58 & 1 \\
\hline \multirow[t]{3}{*}{ Texas } & Houston & 0 & 0 & 1 \\
\hline & Dallas & 0 & 2 & 1 \\
\hline & Austin & 0 & 0 & 1 \\
\hline
\end{tabular}

Int Migr Rev. Author manuscript; available in PMC 2020 June 01. 


\begin{tabular}{llccc}
\hline State & City & $\mathbf{2 0 0 5}$ & $\mathbf{2 0 1 0}$ & $\mathbf{2 0 1 5}$ \\
\hline Utah & Salt Lake City & 0 & 1.83 & 2 \\
& Provo & 0 & 1 & 2 \\
& Park City & 0 & 1 & 2 \\
Virginia & Virginia Beach & 0 & 0 & 1 \\
& Richmond & 0 & 0 & 1 \\
& Charlottesville & 0 & 0 & 1 \\
\multirow{4}{*}{ Washington } & Seattle & 0 & 0 & 0 \\
& Spokane & 0 & 0 & 0 \\
& Tacoma & 0 & 0 & 0 \\
Average & & $\mathbf{0 . 0 3}$ & $\mathbf{0 . 9 6}$ & $\mathbf{0 . 9 7}$ \\
\hline
\end{tabular}

Table B

Description of Dependent Variables

\begin{tabular}{|c|c|}
\hline Variable Name & Definition \\
\hline Arrest Variables: & Question asked: "What was the reason you were detained this last time?" \\
\hline \multirow{5}{*}{$\begin{array}{l}\text { Arrest for Minor } \\
\text { Offense: }\end{array}$} & Equals 1 if respondent's answer to the question is either: \\
\hline & $\begin{array}{l}\text { Traffic related reason (e.g. driving under the influence, driving too fast, } \\
\text { parked in wrong spot, etc.) }\end{array}$ \\
\hline & - $\quad$ Disorderly conduct \\
\hline & - $\quad$ Drug use \\
\hline & Equals 0 otherwise \\
\hline \multirow{3}{*}{$\begin{array}{l}\text { Arrest due to Traffic } \\
\text { Violation }\end{array}$} & Equals 1 if respondent's answer to the question is: \\
\hline & $\begin{array}{l}\text { Traffic related reason (e.g. driving under the influence, driving too fast, } \\
\text { parked in wrong spot, etc.) }\end{array}$ \\
\hline & Equals 0 otherwise \\
\hline \multirow{3}{*}{$\begin{array}{l}\text { Arrest due to } \\
\text { Disorderly Conduct }\end{array}$} & Equals 1 if respondent's answer to the question is: \\
\hline & - $\quad$ Disorderly conduct \\
\hline & Equals 0 otherwise \\
\hline \multirow[t]{3}{*}{ Arrest for Drug Use } & Equals 1 if respondent's answer to the question is: \\
\hline & - $\quad$ Drug use \\
\hline & Equals 0 otherwise \\
\hline $\begin{array}{l}\text { Duration in Detention } \\
\text { (Days) }\end{array}$ & $\begin{array}{l}\text { Question asked: "For how long have you been held in a detention center, prison, or jail } \\
\text { since the last time you were detained?" } \\
\text { The duration is measured in number of days. }\end{array}$ \\
\hline
\end{tabular}

Int Migr Rev. Author manuscript; available in PMC 2020 June 01. 


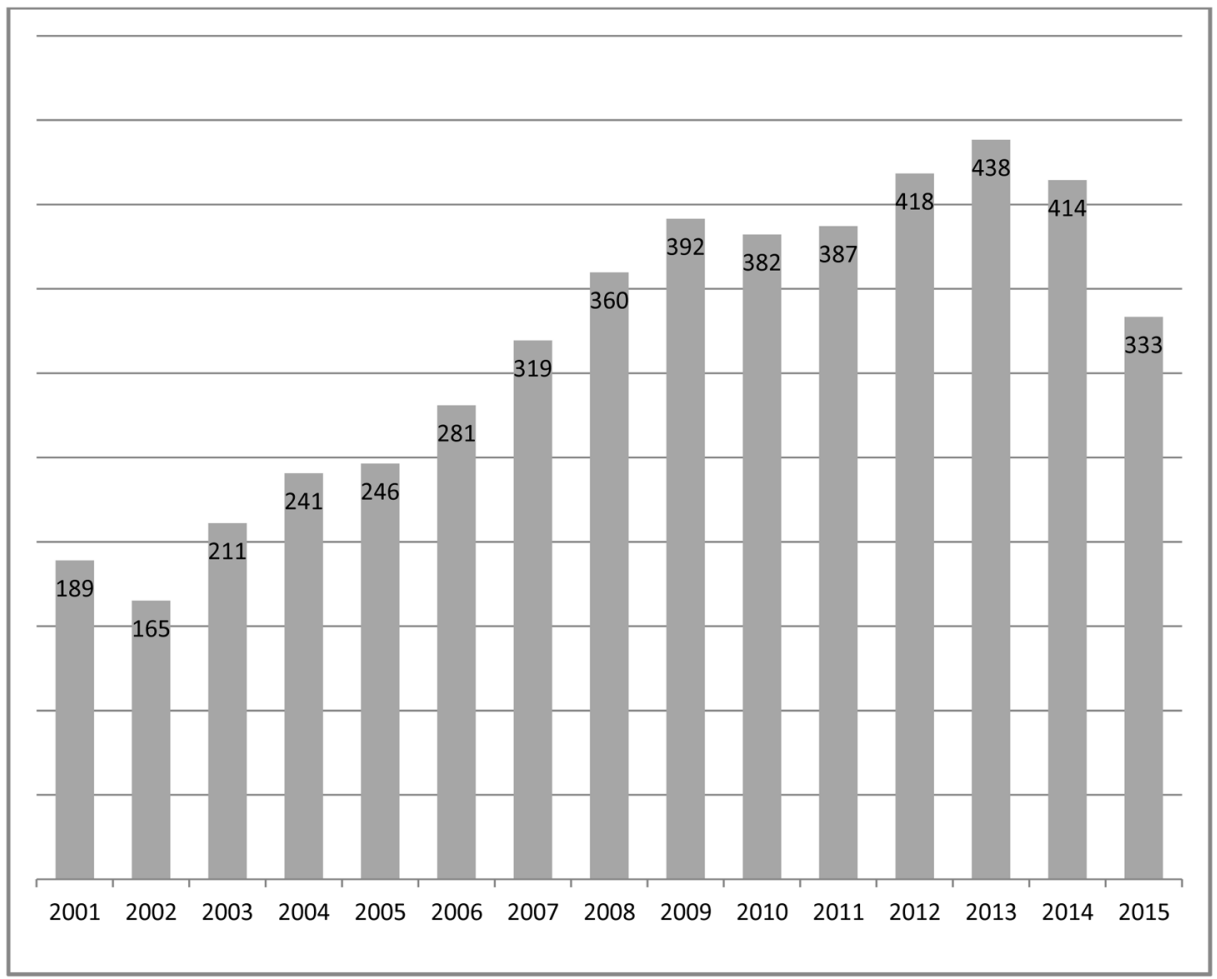

Figure 1. Deportations by U.S. Department of Homeland Security (In thousands, by fiscal year)

Source: Data for 2001-2003 come from U.S. Department of Homeland Security, Yearbook of Immigration Statistics: 2010. Data for 2004-2013 come from U.S. Department of Homeland Security, Yearbook of Immigration Statistics: 2013. Data for 2014 and 2015 come from Yearbook of Immigration Statistics: 2014 and 2015, respectively. 


\section{Table 1}

Descriptive Statistics

\begin{tabular}{lccc}
\hline & & High Level of Enforcement Index \\
\cline { 3 - 4 } & All & Treated Areas & Control Areas \\
\hline Dependent Variables: & & & \\
Detention for Minor Offense & $0.105(0.307)$ & $0.142(0.349)$ & $0.068(0.252)$ \\
$\quad$ Detention due to Traffic Violation & $0.074(0.262)$ & $0.102(0.303)$ & $0.046(0.209)$ \\
$\quad$ Detention due to Disorderly Conduct & $0.025(0.157)$ & $0.036(0.187)$ & $0.014(0.118)$ \\
$\quad$ Detention for Drug Use & $0.013(0.114)$ & $0.016(0.124)$ & $0.011(0.102)$ \\
$\quad$ Duration in Detention (Days) & $262.267(740.327)$ & $248.137(504.172)$ & $276.674(921.035)$ \\
Regressors: & & & \\
Enforcement Index & $0.598(0.695)$ & $1.191(0.505)$ & $0(0)$ \\
Age & $34.172(10.207)$ & $35.016(10.095)$ & $33.319(10.257)$ \\
Male & $0.807(0.395)$ & $0.856(0.351)$ & $0.757(0.430)$ \\
Married & $0.421(0.494)$ & $0.411(0.492)$ & $0.431(0.496)$ \\
Less than High School Education & $0.777(0.416)$ & $0.763(0.426)$ & $0.792(0.407)$ \\
High School Graduate & $0.152(0.359)$ & $0.172(0.377)$ & $0.131(0.338)$ \\
More than High School Education & $0.041(0.198)$ & $0.040(0.196)$ & $0.042(0.201)$ \\
Years in the U.S. & $11.914(10.815)$ & $14.063(11.147)$ & $9.742(10.020)$ \\
Number of Prior Deportations & $1.819(2.975)$ & $1.659(2.607)$ & $1.981(3.300)$ \\
Indigenous Ethnic & $0.071(0.256)$ & $0.064(0.245)$ & $0.077(0.267)$ \\
No. of Observations & $\mathbf{1 1 4 8}$ & $\mathbf{5 7 7}$ & $\mathbf{5 7 1}$ \\
\hline
\end{tabular}

Int Migr Rev. Author manuscript; available in PMC 2020 June 01. 


\section{Table 2}

\section{Likelihood of Being Arrested for Minor Offenses}

\begin{tabular}{|c|c|c|c|c|}
\hline Key Regressors & (1) Baseline Model & (2) Plus Controls & (3) Plus County FE & (4) Plus County \&Time Trends \\
\hline Enforcement Index & $0.260 * * *(0.023)$ & $0.204^{* * *}(0.020)$ & $0.164^{* * *}(0.014)$ & $0.191^{* * *}(0.003)$ \\
\hline Enforcement Index * After 2012 & $-0.211^{* * *}(0.008)$ & $-0.180^{* * *}(0.010)$ & $-0.164^{* * *}(0.008)$ & $-0.233^{* * *}(0.008)$ \\
\hline Age & & $-0.002^{* * *}(4.60 \mathrm{e}-04)$ & $-0.002^{* * *}(2.21 \mathrm{e}-04)$ & $-0.001^{* * *}(8.04 \mathrm{e}-05)$ \\
\hline Male & & $0.077^{* * *}(0.007)$ & $0.061^{* * *}(0.001)$ & $0.072^{* * *}(4.27 \mathrm{e}-04)$ \\
\hline Married & & $-0.023^{* * *}(0.005)$ & $-0.033^{* * *}(0.005)$ & $-0.029^{* * * *}(0.005)$ \\
\hline High School Graduate & & $-0.037^{* * *}(0.010)$ & $-0.027^{* * *}(0.002)$ & $-0.025^{* * *}(0.004)$ \\
\hline More than High School Education & & $0.059 *(0.032)$ & $0.026(0.025)$ & $0.008(0.016)$ \\
\hline Years in the U.S. & & $0.006^{* * *}(2.24 \mathrm{e}-04)$ & $0.004^{* * *}(3.18 \mathrm{e}-04)$ & $0.005^{* * *}(1.14 \mathrm{e}-04)$ \\
\hline Number of Prior Deportations & & $-0.007^{* * *}(0.002)$ & $-0.005^{* * *}(0.002)$ & $-0.007^{* * *}(0.001)$ \\
\hline Indigenous Ethnic & & $-0.142^{* * *}(0.010)$ & $-0.034^{* * *}(0.002)$ & $-0.017^{* * *}(3.38 \mathrm{e}-04)$ \\
\hline County Fixed Effects (FE) & $\mathrm{N}$ & $\mathrm{N}$ & $\mathrm{Y}$ & $\mathrm{Y}$ \\
\hline Year Fixed Effects (FE) & $\mathrm{N}$ & $\mathrm{N}$ & $\mathrm{N}$ & $\mathrm{Y}$ \\
\hline FEs and Time Trends & $\mathrm{N}$ & $\mathrm{N}$ & $\mathrm{N}$ & $\mathrm{Y}$ \\
\hline $\mathrm{R}^{2}$ & 0.039 & 0.099 & 0.169 & 0.216 \\
\hline Observations & 1,148 & 1,148 & 1,148 & 1,148 \\
\hline
\end{tabular}

Notes: All regressions include a constant term. Standard errors are displayed in parentheses. $* * * * * *$

denote $1 \%, 5 \%, 10 \%$ levels of significance, respectively. 


\section{Table 3}

Likelihood of Being Arrested for Minor Offenses

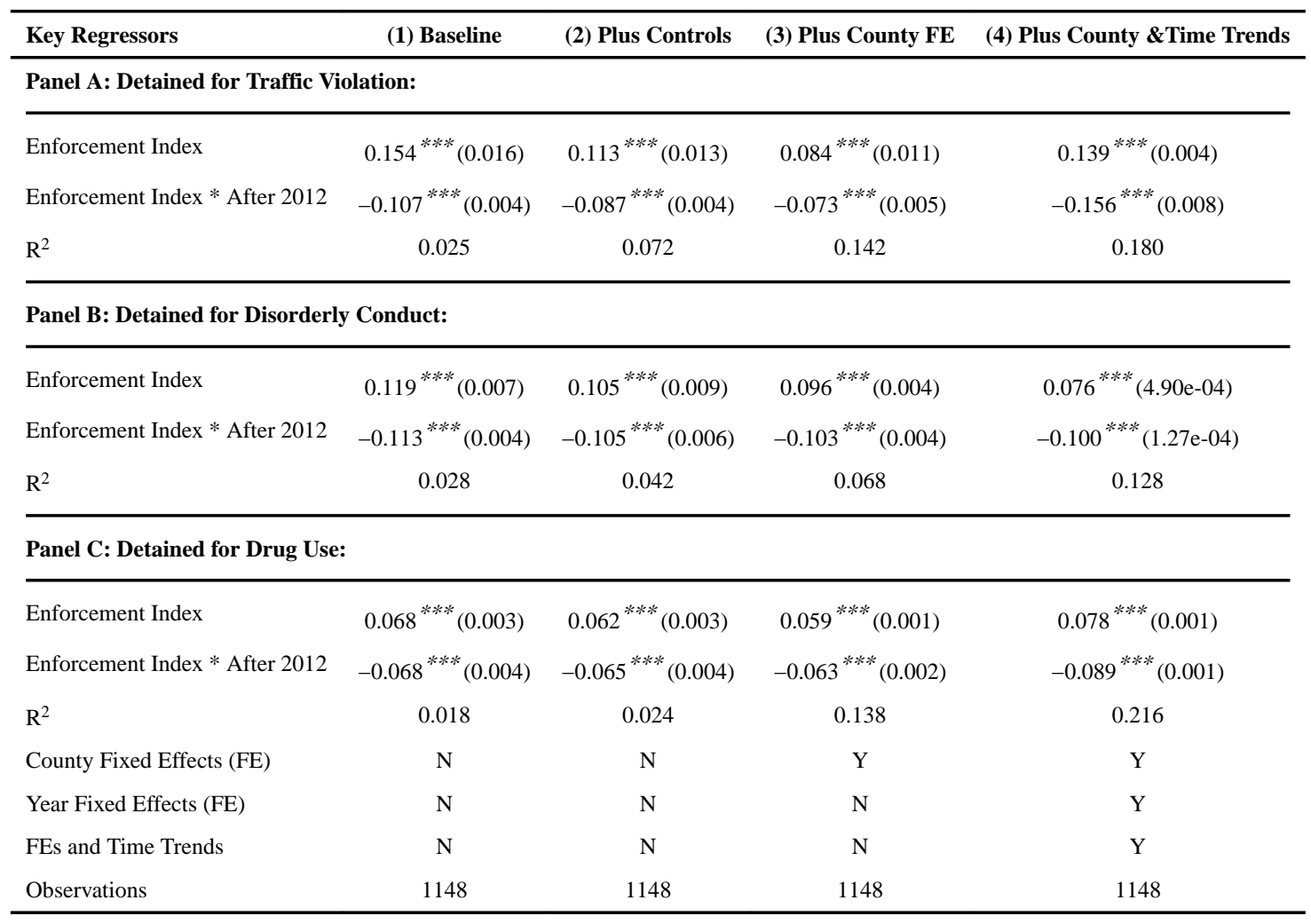

Notes: All regressions include a constant term and other regressors as in Table 2. Standard errors are displayed in parentheses. $* * * * * * *$

denote $1 \%, 5 \%, 10 \%$ levels of significance, respectively. 

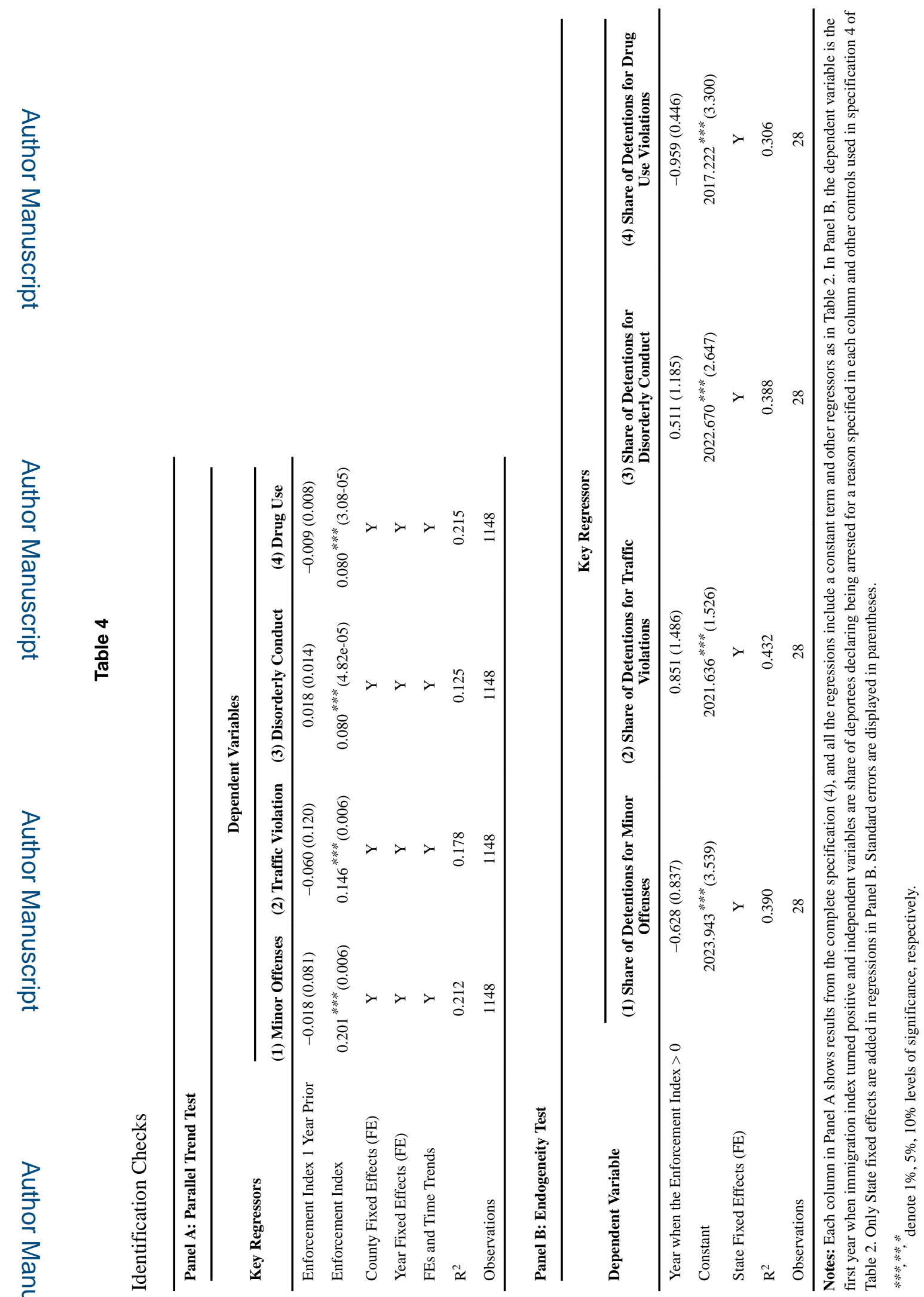

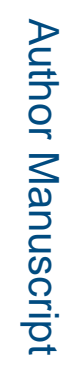

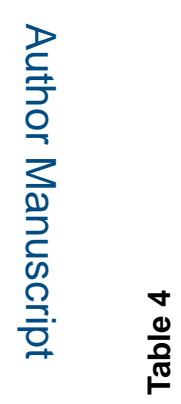

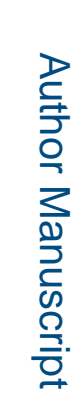

Int Migr Rev. Author manuscript; available in PMC 2020 June 01. 
Table 5

Robustness Checks

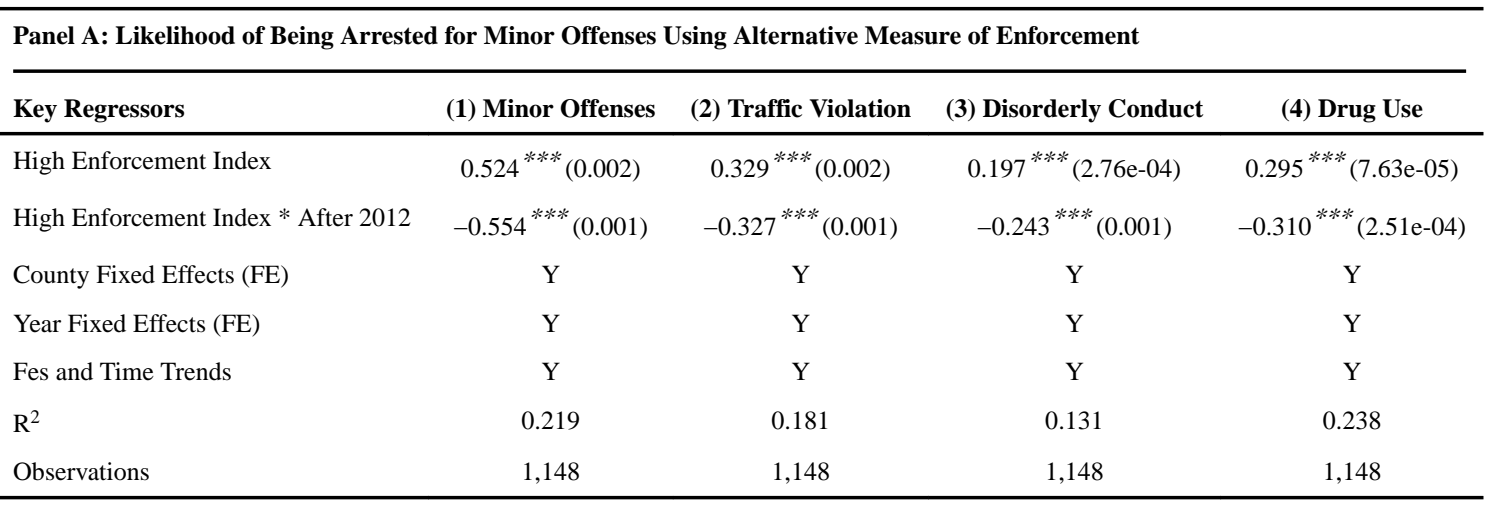

Panel B: Likelihood of Being Arrested for Minor Offenses by Whether the Locality Had a Trust Act

\begin{tabular}{lcc}
\hline \multirow{2}{*}{ Key Regressors } & \multicolumn{2}{c}{ Minor Reasons } \\
\cline { 2 - 3 } & (1) Areas with a Trust Act & (2) Areas without a Trust Act \\
\hline Enforcement Index & $-0.022^{* * *}(1.18 \mathrm{e}-04)$ & $0.197^{* * *}(0.005)$ \\
Enforcement Index * After 2012 & - & $-0.302^{* * *}(0.060)$ \\
County Fixed Effects (FE) & $\mathrm{Y}$ & $\mathrm{Y}$ \\
Year Fixed Effects (FE) & $\mathrm{Y}$ & $\mathrm{Y}$ \\
FEs and Time Trends & $\mathrm{Y}$ & $\mathrm{Y}$ \\
$\mathrm{R}^{2}$ & 0.162 & 0.326 \\
Observations & 918 & 230 \\
\hline
\end{tabular}

Panel C: Likelihood of Being Arrested by Whether the Locality Issued Driver Licenses to Undocumented Immigrants

Traffic Violations

\begin{tabular}{lcc}
\cline { 2 - 3 } Key Regressors & $\begin{array}{c}\text { (1) Areas Offering Driver's Licenses to } \\
\text { Immigrants }\end{array}$ & $\begin{array}{c}\text { (2) Areas That Do Not Offer Driver's Licenses to } \\
\text { Immigrants }\end{array}$ \\
\hline Enforcement Index & $3.39 \mathrm{e}-04(1.56 \mathrm{e}-04)$ & $0.139 * * *$ \\
$(0.003)$ \\
Enforcement Index * After 2012 & - & $-0.193 * 3^{* * *}(0.036)$ \\
County Fixed Effects (FE) & $\mathrm{Y}$ & $\mathrm{Y}$ \\
Year Fixed Effects (FE) & $\mathrm{Y}$ & $\mathrm{Y}$ \\
FEs and Time Trends & $\mathrm{Y}$ & $\mathrm{Y}$ \\
$\mathrm{R}^{2}$ & 0.207 & 0.187 \\
Observations & 776 & 372 \\
\hline
\end{tabular}

Notes: Each column in both panels shows results from the complete specification (4), and all the regressions include a constant term and other regressors as in Table 2. Standard errors are displayed in parentheses.

******* denote 1\%, 5\%, 10\% levels of significance, respectively. In Panels B and C, the interaction term "Enforcement Index * After 2012" drops in columns 1 because Trust Act is activated after 2012 and majority of states allowing driver's licenses to migrants enacted it after 2012 . 


\section{Table 6}

\section{Detention Duration}

\begin{tabular}{lcccc}
\hline Key Regressors & (1) Baseline & (2) Plus Controls & (3) Plus County FE & $\begin{array}{c}\text { (4) Plus County \&Time } \\
\text { Trends }\end{array}$ \\
\hline Enforcement Index & $1020.031^{* * *}(53.010)$ & $823.244^{* * *}(54.840)$ & $627.226^{* * *}(13.729)$ & $345.336^{* * *}(10.151)$ \\
Enforcement Index * After 2012 & $-1087.544^{* * *}(40.968)$ & $-946.784^{* * *}(26.873)$ & $-859.168^{* * *}(11.454)$ & $-361.303^{* * *}(12.181)$ \\
County Fixed Effects (FE) & $\mathrm{N}$ & $\mathrm{N}$ & $\mathrm{Y}$ & $\mathrm{N}$ \\
Year Fixed Effects (FE) & $\mathrm{N}$ & $\mathrm{N}$ & $\mathrm{N}$ & $\mathrm{Y}$ \\
FEs and Time Trends & $\mathrm{N}$ & $\mathrm{N}$ & $\mathrm{Y}$ \\
$\mathrm{R}^{2}$ & 0.102 & 0.181 & 0.299 & 0.886 \\
Observations & 1,135 & 1,135 & 1,135 \\
\hline
\end{tabular}

Notes: Detentionduration is measured in days. All regressions include a constant term and other regressors as in Table 2. Standard errors are displayed in parentheses.

$* * * * *{ }^{*}$ denote $1 \%, 5 \%, 10 \%$ levels of significance, respectively. 